KOMPARTEMEN: JURNAL ILMIAH AKUNTANSI

September 2020, Volume XIX, No. 2, 85-98

\title{
ANALISA PENGARUH INTELLECTUAL CAPITAL, ISLAMICITY PERFORMANCE INDEX DAN CORPORATE SOCIAL RESPONSIBILITY TERHADAP PROFITABILITAS (Studi pada Bank Umum Syariah periode tahun 2014-2018)
}

\author{
Dwi Yuliana Rahayu1, Tuti Kurniati ${ }^{2}$, Sri Wahyuni ${ }^{3}$ \\ Universitas Muhammadiyah Purwokerto ${ }^{123}$ \\ dwiyulianar77@gmail.com ${ }^{1}$
}

\begin{abstract}
The aim of this research is to know the influence of intellectual capital, islamicity performance index and corporate social responsibility on profitability. Theories used are stakeholder theory. This research conducted on Indonesia Islamic banking in 2014-2018. The sample were 13 banks, by non probability sampling method with purposive sampling technique. The analysis technique used is multiple linear analysis. Based on the analysis found that zakat performance ratio and islamic social reposting have positive effect on profitability. Intellectual capital, profit sharing ratio, and equitable distribution ratio have no effect on profitability.
\end{abstract}

Keywords: intellectual capital; profit sharing ratio; zakat performance ratio; equitable distribution ratio; Islamic social reporting; profitability

\begin{abstract}
ABSTRAK
Tujuan dari penelitian ini adalah untuk mengetahui bagaimana pengaruh intellectual capital, islamicity performance index dan corporate social repsonsibility terhadap profitabilitas. Teori yang digunakan adalah teori stakeholder. Penelitian ini dilakukan pada bank umum syariah di Indonesia tahun 2014-2018. Jumlah sampel yang digunakan sebanyak 13 sampel dengan metode non probability sampling dengan teknik purposive sampling. Teknik analisis yang digunakan adalah analisis regresi linear berganda. Berdasarkan hasil analisis ditemukan bahwa zakat performance ratio dan islamic social reporting berpengaruh positif terhadap profitabilitas. Intellectual capital, profit sharing ratio dan equitable distribution ratio tidak berpengaruh terhadap profitabilitas.
\end{abstract}

Kata kunci: intellectual capital; profit sharing ratio; zakat performance ratio; equitable distribution ratio; Islamic social reporting; profitabilitas

\section{PENDAHULUAN}

Perbankan syariah merupakan lembaga keuangan yang menghimpun dana dari masyarakat dengan menggunakan prinsip prinsip syariah. Berdirinya perbankan syariah di Indonesia ketika pemerintah mengeluarkan UU No 7 tahun 1992 dan ditandai dengan berdirinya Bank Muamalat Indonesia. Pada tahun 1998 pemerintah merevisi UU tersebut menjadi UU No 10 tahun 1998 tentang peraturan yang memperbolehkan setiap bank konvensional membuka system pelayanan syariah. Perbankan syariah di Indonesia kini berkembang sangat pesat. Hal ini dapat 
disebabkan oleh banyaknya pemeluk agama islam di Indonesia sehingga memungkinkan angka minat masyarakat untuk menggunakan layanan perbankan syariah menjadi tinggi (Putri \& Gunawan, 2019). Statistik otoritas jasa keuangan (2018) juga menunjukan bahwa jumlah bank umum syariah kini semakin banyak yaitu berjumlah 14 bank.

Sistem keuangan dan perbankan syariah merupakan bagian dari konsep yang lebih luas tentang ekonomi islam yang tujuannya adalah memberlakukan system nilai dan etika islam ke dalam lingkungan ekonomi (Wahyuni \& Pujiharto, 2018). Melihat perkembangan dan pentingnya peranan perbankan syariah, maka kinerja perbankan pun harus ditingkatkan. Kinerja keuangan merupakan salah satu aspek yang fundamental mengenai kondisi keuangan perusahaan, untuk kinerja keuangan perbankan syariah dapat dianalisis dengan rasio profitabilitas yang diukur menggunakan Return On Assets (ROA) (Pudyastuti, 2018).

Return on Assets (ROA) merupakan pengukuran kemampuan perusahaan secara keseluruhan di dalam menghsilkan keuntungan dengan total aktiva yang terdapat pada perusahaan (Pratiwi et al., 2020). Beberapa faktor non finansial yang dapat meningkatkan kinerja perusahaan seperti corporate social responsibility dan intellectual capital. Corporate social responsibility merupakan suatu program tanggung jawab perusahaan terhadap social dan lingkungan sekitar perusahaan seperti pemerintah, karyawan dan konsumen. Modal intelektual atau intellectual capital merupakan suatu konsep yang dapat memberikan sumber daya berbasis pengetahuan baru dan mendeskripsikan aset tak berwujud yang jika digunakan secara optimal memungkinkan perusahaan untuk menjalankan strateginya secara efektif dan efisien.

Fenomena intellectual capital di Indonesia bermula dengan ditandai terbitnya PSAK No 19 (revisi 2012) tentang aktiva tidak berwujud (Prastuti \& Budiasih, 2019). Pengungkapan CSR disuatu perusahaan dapat memfasilitasi pemantauan eksternal terhadap kinerja keuangan perusahaan dan dengan demikian memberikan intensif kepada perusahaan untuk mengurangi kebijakan mereka (Chen et al., 2018).

Perbankan syariah merupakan suatu lembaga keungan yang dijalankan dengan prinsip syariah yang tentunya memiliki karakter yang berbeda dengan perusahaan lain dalam dalam orientasi kinerjanya. Oleh karena itu kinerja perbankan syariah juga harus diukur dengan metode yang berorientasi pada tujuan syariah (Dewanata et al., 2016). Ibrahim et.al. (2003) menyajikan sebuah alternatif pengukuran kinerja untuk perbankan syariah yaitu dengan sebuah indeks yang dinamakan dengan islamicity performance index (Rahma, 2018). Islamicity performance index berkaitan dengan kinerja organisasi. Namun pengukuran kinerja hanya didasari pada informasi yang tersedia pada annual report. Informasi ini mencangkup kinerja bagi hasil, kinerja distribusi yang adil, kesejahteraan direksi dan karyawan, investasi halal, investasi non halal, pendapatan halal dan pendapatan non halal (Bustamam \& Aditia, 2016).

\section{TINJAUAN PUSTAKA DAN PENGEMBANGAN HIPOTESIS Stake Holder Theory}

Menurut Ghozali dan Cahriri (2007) stake holder theory menyatakan bahwa perusahaan bukanlah entitas yang hanya beroperasi untuk kepentingan sendiri namun harus memberikan 
manfaat bagi stakeholder. Dengan demikian keberadaan suatu perusahaan sangat dipengaruhi oleh motivasi yang diberikan stakeholder kepada perusahaan tersebut. Menurut Prasetyo (2014) menyatakan bahwa stakeholder memiliki hak untuk diperlakukan dengan adil oleh perusahaan. Meek dan Gray (1988) dalam Dewanata et.al (2016) menjelaskan bahwa stakeholder theory laba akuntansi merupakan ukuran return bagi pemegang saham, sedangkan value added merupakan ukuran yang lebih akurat yang diciptakan oleh stakeholder yang sama.

\section{Intellectual Capital}

Menurut Swarjuwono dan Kadir (2003) modal intelektual (intellectual capital) dapat didefinisikan sebagai jumlah dari apa yang dihasilkan oelh tiga elemen utama organisasi (human capital, structural capital dan consumer capital) yang berkaitan dengan pengetahuan dan teknologi yang dapat memberikan nilai lebih bagi perusahaan berupa keunggulan bersaing organisasi (Febriany, 2019). Menurut Sugeng (2002) modal intelektual mengacu pada pengetahuan dan kemampuan yang dimiliki suatu kolektivitas sosial seperti organisasi, komunitas intelektual, atau praktek profesional (Wijayani, 2017).

\section{Islamicity Performance Index}

Islamicity performance index adalah pengukuran kinerja yang mampu mengekspresikan nilai nilai syariah yang terdapat pada bank syariah (Lisa, 2017). Hameed et.al (2004) merumuskan islamicity performance index untuk mengukur kinerja perbankan telah sesuai dengan prinsip prinsip syariah (Dewanata et al., 2016).

\section{Corporate Social Responsibillity}

Menurut Poerwanto (2010), corporate social responsibility (CSR) merupakan jiwa perusahaan untuk mencapai tujuan bisnis yang mencangkup citra perusahaan, promosi, meningkatkan penjualan, membangun percaya diri, loyalitas karyawan serta keuntungan. Tujuan CSR adalah meningkatkan kualitas hidup masyarakat dan lingkungan dan lingkungan terutama yang berada pada lingkungan perusahaan (Puspitaningtyas et al., 2018). Dalam penelitian ini

CSR diukur dengan Islamic social reporting (ISR). ISR mencerminkan respon kepercayaan positif baik pemegang saham maupun pemangku kepentingan ditunjukan oleh produk perusahaan (Herwanti dan Irwan, 2017).

\section{Profitabilitas}

Profitabilitas merupakan pendapatan bersih dari berbagai kebijakan dan keputusan yang dilakukan oleh perusahaan dimana rasio ini digunakan sebagai alat untuk mengukur atas 
kemampuan perusahaan dalam memperoleh laba. Dengan demikian pengukuran profitabilitas suatu perusahaan menunjukan tingkat efektivitas manajemen secara menyeluruh dan secara tidak langsung para investor jangka panjang akan sangat berkepentingan dengan analisis ini. Indikator yang digunakan untuk mengukur ptofitabillitas salah satunya adalah Return On Assets (Pratiwi et al., 2020).

\section{Pengembangan Hipotesis}

\section{Pengaruh intellectual capital terhadap profitabilitas}

Intellectual capital yaitu sumber daya yang dimiliki perusahaan berupa sumber daya intelektual, baik sumber daya manusia, modal organisasi maupun modal pelanggan. Intellectual capital yang dikelola dengan baik oleh perusahaan dapat menciptakan nilai tambah bagi perusahaan sehingga dapat meningkatkan kinerja keuangan perusahaan. Penelitian dari Nurdin \& Suyudi (2019) menemukan bukti empiris bahwa intellectual capital berpengaruh positif terhadap return on asset perusahaan. berdasarkan uaraian diatas maka dirumuskan hipotesis sebagai berikut:

H1: intellectual capital berpengaruh positif terhadap profitabilitas

\section{Pengaruh profit sharing ratio terhadap profitabilitas}

Profit sharing ratio menunjukan seberapa jauh perbankan syariah mencapai eksistensi dengan perolehan bagi hasil dari pemberian pembiayaan kepada nasabah. Bagi hasil merupakan komponen penting dalam perbankan syariah, sehingga pembiayaan bagi hasil merupakan pembiayaan terpenting dalam perbankan syariah. Pudyastuti (2018) dalam penelitiannya memberikan bukti empiris bahwa profit sharing ratio berpengaruh positif terhadap kinerja keuangan bank syariah yang diproksikan dengan ROA. Berdasarkan uraian tersebut maka dapat diarik hipotesis:

H2: Profit sharing ratio berpengaruh positif terhadap profitabilitas

\section{Pengaruh zakat performance ratio terhadap profitabilitas}

Zakat merupakan salah satu perintah yang ada di dalam agama Islam, maka harus menjadi salah satu tujuan dalam akuntansi syariah. Oleh karena itu kinerja perbankan syariah juga harus berdasarkan pada zakat. Rahma, (2018) memberikan bukti empiris bahwa zakat performance ratio berpengaruh positif terhadap kinerja keuangan yang dihitung berdasarkan return on assets (ROA). Berdasarkan penjelasan tersebut maka dapat ditarik hipotesis: 
H3: Zakat performance ratio berpengaruh positif terhadap profitabilitas

\section{Pengaruh equitable distribution ratio terhadap profitabilitas}

Equitable distribution ratio (EDR) merupakan indkator yang menjelaskan performa distribusi pendapatan yang diperoleh bank syariah kepada stakeholder. EDR mengungkapkan seberapa besar pendapatan yang didistribusikan kepada stakeholder (penerima qard, donasi, pegawai bank, dan pemegang saham) serta laba bersih untuk bank. Pudyastuti, (2018) menyatakan bahwa equitable distribution ratio tidak berpengaruh terhadap kinerja keuangan yang diproksikan dengan ROA. Berdasarkan penjelasan tersebut maka dapat ditarik hipotesis:

H4: Equitable distribution ratio berpengaruh positif terhadap profitabilitas

\section{Pengaruh Islamic social reporting terhadap proftabilitas}

Islamic social reporting merupakan variabel yang menunjukan besarnya pertanggungjawaban sosial perusahaan terhadap publik. Setiap agenda dalam pengungkapan ISR dapat membantu perusahaan dalam mencaga citranya dihadapan publik. Semakin banyak perusahaan mengungkapkan pertanggungjawaban sosial yang diharapkan akan memberikan pengaruh terhadap profitabilitas. Harahap et al., (2017) menyimpulkan bahwa Islamic social reporting memberikan pengaruh terhadap profitabilitas. Nasution et al., (2019) juga menyimpulkan bahwa ISR berpengaruh positif terhadap profitabilitas. Berdasarkan uraian tersebut dapat ditarik hipotesis:

H5: Islamic social reporting berpengaruh positif terhadap profitabilitas

\section{METODE PENELITIAN}

\section{Populasi dan Sampel}

Populasi adalah wilayah yang secara umum terdiri dari obyek atau subyek yang mempunyai kualitas dan karakteristik yang ditetapkan oleh peneliti (Sugiyono, 2016). Populasi dalam penelitian ini adalah bank umum syariah yang beroperasi pada tahun 2014-2018. Sampel adalah bagian yang memenuhi karakteristik dari populasi (Sugiyono, 2016:81). Sampel dalam penelitian kali ini adalah 13 bank umum syariah.

\section{Metode pengambilan sampel}

Metode pengambilan sampel dalam penelitian ini yaitu dengan cara mengambil sampel sesuai dengan kriteria kriteria yang ditetapkan (purposive sampling). Kriteria tersebut adalah: (1) Bank umum syariah yang menerbitkan annual report secara lengkap pada tahun 2014-2018; (2) Bank 
umum yang menyajikan variabel yang ada didalam penelitian ini secara lengkap.

\section{Jenis data dan sumber data}

Jenis data dalam penelitian ini adalah data sekunder yaitu berasal dari annual report bank umum syariah tahun 2014-2018. Data ini bersumber dari Bursa efek Indonesia, statistik perbankan syariah serta website masing masing bank.

\section{Metode pengumpulan data}

Metode pengumpulan data yang digunakan dalam penelitian ini adalah metode dokumentasi, yaitu dengan cara merekam atau mendokumentasikan data penelitian yang diperlukan.

\section{Varabel penelitian}

Variabel yang digunakan dalam penelitian ini terdiri dari variabel dependent yaitu profitabilitas dan variabel independent yaitu intellectual capital, islamicity performance index yang diukur dengan profit sharing ratio, zakat performance ratio dan equitable distribution ratio serta corporate social responsibility yang diukur dengan Islamic social reporting.

\section{Definisi dan pengukuran variabel}

\section{Intellectual Capital}

Intellectual capital adalah suatu aset tidak berwujud yang dimiliki perusahaan terkait kualitas sumber daya manusia dan teknologi yang dijadikan sebagai keunggulan kompetitif perusahaan (Nurdin \& Suyudi, 2019). Ulum (2013) dalam Putri \& Gunawan (2019) sudah mengembangkan alat ukur VAIC agar menjadi lebih relevan digunakan untuk mengukur kinerja intellectual capital pada perbankan syariah yang dinamakan iB-VAIC. iB-VAIC terdiri dari beberapa elemen yaitu:

a) Value added capital employee (VACA)

$$
\mathrm{iB}-\mathrm{VACA}=\frac{\text { Value added }}{\text { Capital Employee }}
$$

b) Islamic banking value added human capital (iB-VAHU)

$$
\mathrm{iB}-\mathrm{VAHU}=\frac{\text { Value Added }}{\text { Human Capital }}
$$

c) Islamic banking structural capital value added (iB- STVA)

$$
\mathrm{iB-STVA}=\frac{\text { Value added }}{\text { Structural Capital }}
$$




\section{Islamicity performance index}

Menurut Algoud dan Assegaf (2012) dalam Nurdin dan Suyudi (2019) tujuan utama perbankan dan keuangan islam dari persepektif islam adalah mencangkup: (1) penghapusan bunga dan memperbaharui aktivitas bank agar berjalan sesuai dengan prinsip islam; (2) distribusi pendapatan dan kekayaan wajar; dan (3) mencapai kemajuan di bidang ekonomi. Dalam penelitian ini indikator yang digunakan adalah Profit Sharing Ratio, Zakat Performance Ratio, dan Equitable Distribution Ratio.

a. Profit Sharing Ratio (PSR)

Profit Sharing Ratio dihitung dengan menjumlahkan akad mudharabah dan musyarakah yang selanjutnya dibandingkan dengan total pembiayaan.

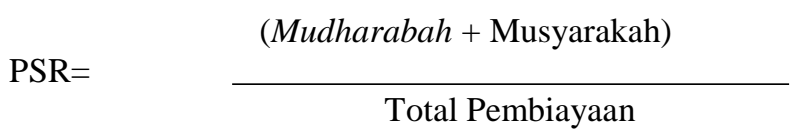

b. Zakat Performance Ratio (ZPR)

Kinerja perbankan syariah harus di dasarkan pada zakat yang dibayarkan untuk menggantikan earning per share dalam perbankan konvensional. Adapun rumus untuk menghiung ZPR adalah:

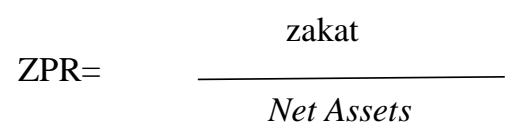

\section{c. Equitable Distribution Ratio (EDR)}

Rasio ini dihitung dengan cara menjumlahkan dana yang dikeluarkan untuk qardh dan dana kebajikan, upah karyawan, pemegang saham dan laba bersih. Berikut adalah rumus rumus untuk menghitung EDR

$$
\begin{aligned}
& \text { Qardh \& Donation }=\frac{\text { Qardh \& Donation }}{\text { Revenue }-(\text { Zakat }+ \text { Tax })} \\
& \text { Employees Expense }=\frac{\text { Labor Costs }}{\text { Revenue }-(\text { Zakat }+ \text { Tax })} \\
& \text { Shareholders }=\frac{\text { Deviden }}{\text { Revenue }-(\text { Zakat }+ \text { Tax })} \\
& \text { Net Profit }= \\
& \text { Revenue }-(\text { Zakat }+ \text { Tax })
\end{aligned}
$$




\section{Corporate Social Responsibility}

Salah satu bentuk tanggung jawab suatu perusahaan adalah dengan ditunjukan melalui tanggung jawab sosial atau lebih dikenal dengan nama Corporate Social Responsibility (CSR). CSR didalam perbankan syariah dapat diukur dengan menggunakan Islamic Social Reporting (ISR). ISR merupakan standar pelaporan kinerja sosial untuk perusahaan yang berbasis syariah (Ridhawati, 2020).

$$
\mathrm{ISR}=\frac{\text { Jumlah yang diungkapkan }}{\text { Jumlah maksimum pengungkapan }}
$$

\section{Profitabilitas}

Profitabilitas adalah tingkat keuntungan yang diperoleh perusahaan. Profitabilitas dalam penelitian ini diukur dengan menggunakan Return on Assets (ROA).

$$
\mathrm{ROA}=\frac{\text { Laba sebelum pajak }}{\text { Rata-rata aset }}
$$

\section{Metode Analisis Data}

Teknik pengujian hipotesis yang dilakukan dalam penelitian ini adalah regresi linier berganda. Model regresi yang baik maka data harus berdistribusi normal dan bebas dari asumsi klasik. Persamaan regresi linier berganda pada penelitian ini adalah:

$\mathrm{Y}=\alpha+\beta \mathrm{X} 1+\beta \mathrm{X} 2+\beta \mathrm{X} 3+\beta \mathrm{X} 4+\beta \mathrm{X} 5+\mathrm{e}$

\section{Hasil Penelitian dan Pembahasan}

\section{Statistik Deskriptif}

Statistik deskriptif dalam penelitian ini terlihat pada tabel 1.

Tabel 1. Statistik Deskriptif

\begin{tabular}{|l|r|r|r|r|r|}
\hline & $\mathrm{N}$ & \multicolumn{1}{|c|}{ Minimum } & Maximum & \multicolumn{1}{c|}{ Mean } & Std. Deviation \\
\hline ROA & 65 &,- 073370 &, 498650 &, 01951862 &, 065590693 \\
IC & 65 & $-2,568950$ & 20,050300 & 4,33608262 & 3,681665566 \\
PSR & 65 &, 000000 & 1,061760 &, 44215723 &, 353852075 \\
ZPR & 65 &, 000000 &, 020190 &, 00085631 &, 003047822 \\
EDR & 65 & $-1,956590$ & 20,404880 &, 66543892 & 2,737632068 \\
ISR & 65 &, 421053 &, 789474 &, 60769242 &, 092424694 \\
Valid N (listwise) & 65 & & & & \\
\hline
\end{tabular}

Sumber: data diolah 
Berdasarkan tabel 1, standar deviasi ROA sebesar 6,5\% lebih kecil dari rata rata yaitu 1,9\%. Standar deviasi IC selama periode penelitian adalah sebesar 3,68, lebih kecil dari rata ratanya yaitu 4,33. Standar deviasi PSR sebesar 0,35 lebih kecil dari nilai rata ratanya yaitu 0,44. Standar deviasi ZPR sebesar 0,003. Hal tersebut menunjukan standar deviasi lebih kecil dari nilai rata ratanya yaitu 0,0008. Standar deviasi EDR sebesar 2,73 lebih besar dari nilai rata ratanya yaitu 0,66. Standar deviasi ISR sebesar 0,092 lebih kecil dari rata rata yaitu 0,60.

\section{Uji Normalitas}

Tabel 2. Hasil Uji Kolmogorov-Smirnov

\begin{tabular}{|c|c|c|}
\hline & & $\begin{array}{l}\text { Standardized } \\
\text { Residual }\end{array}$ \\
\hline $\begin{array}{l}\text { N } \\
\text { Normal Parameters }{ }^{a, b} \\
\text { Most Extreme Differences } \\
\text { Test Statistic } \\
\text { Asymp. Sig. (2-tailed) }\end{array}$ & $\begin{array}{l}\text { Mean } \\
\text { Std. Deviation } \\
\text { Absolute } \\
\text { Positive } \\
\text { Negative }\end{array}$ & $\begin{array}{r}46 \\
.0000000 \\
.94280904 \\
.112 \\
.112 \\
-.056 \\
.112 \\
.193^{c}\end{array}$ \\
\hline
\end{tabular}

Sumber: data diolah

Tabel 2. menunjukan bahwa nilai residual data pada penelitian ini bersifat normal karena Asymp Sig (2-tailed) sebesar 0,93 atau lebih besar dari 0,05.

\section{Uji Multikolinearitas}

\section{Tabel 3. Hasil Uji Multikolinearitas}

\begin{tabular}{|c|c|c|c|c|c|c|c|}
\hline \multirow[b]{2}{*}{ Model } & \multicolumn{2}{|c|}{$\begin{array}{c}\text { Unstandardized } \\
\text { Coefficients }\end{array}$} & \multirow{2}{*}{$\begin{array}{c}\text { Standardized } \\
\text { Coefficients } \\
\text { Beta } \\
\end{array}$} & \multirow[b]{2}{*}{$t$} & \multirow[b]{2}{*}{ Sig. } & \multicolumn{2}{|c|}{ Collinearity Statistics } \\
\hline & $\mathrm{B}$ & Std. Error & & & & Tolerance & VIF \\
\hline $1 \quad$ (Constant) & .027 & .006 & & 4.630 & .000 & & \\
\hline IC & 8.019E-5 & .000 & .041 & .360 & .721 & .773 & 1.294 \\
\hline PSR & -.009 & .003 & -.391 & -3.521 & .001 & .826 & 1.211 \\
\hline ZPR & -1.340 & .314 & -.520 & -4.261 & .000 & .684 & 1.462 \\
\hline EDR & .001 & .000 & .508 & 4.666 & .000 & .858 & 1.165 \\
\hline ISR & -.025 & .009 & -.287 & -2.678 & .011 & .886 & 1.128 \\
\hline
\end{tabular}

Sumber: Data diolah

Berdasarkan data diatas dapat dilihat bahwa nilai VIF semua variabel kurang dari 10. Maka dapat disimpulkan model tidak ada gejala multikolinearitas. 


\section{Uji Heteroskedastisitas}

\section{Tabel 4. Hasil Uji Heteroskedastisitas}

\begin{tabular}{|l|r|r|r|r|r|}
\hline \multirow{2}{*}{ Model } & \multicolumn{2}{|c|}{$\begin{array}{c}\text { Unstandardized } \\
\text { Coefficients }\end{array}$} & \multicolumn{2}{c|}{$\begin{array}{c}\text { Standardized } \\
\text { Coefficients }\end{array}$} & \\
\cline { 2 - 4 } & \multicolumn{1}{|c|}{$\mathrm{B}$} & Std. Error & \multicolumn{1}{c|}{ Beta } & \multicolumn{1}{c|}{$\mathrm{t}$} & \multicolumn{1}{c|}{ Sig. } \\
\hline 1 (Constant) & .005 & .003 & & 1.503 & .141 \\
IC & $-2.975 \mathrm{E}-5$ & .000 & -.044 & -.252 & .802 \\
PSR & .000 & .001 & .042 & .247 & .806 \\
ZPR & -.147 & .167 & -.165 & -.880 & .384 \\
EDR & $-9.074 \mathrm{E}-5$ & .000 & -.110 & -.661 & .512 \\
ISR & -.001 & .005 & -.024 & -.147 & .884 \\
\hline
\end{tabular}

Sumber : data diolah

Berdasarkan data diatas diketahui bahwa nilai signifikan semua variabel lebih dari 0,05 maka dapat disimpulkan bahwa model tidak mengandung gejala heteroskedastisitas.

\section{Uji Otokorelasi}

Tabel 5. Hasil Uji Otokorelasi

\begin{tabular}{|l|r|r|r|r|r|}
\hline Model & $\mathrm{R}$ & R Square & \multicolumn{1}{c|}{$\begin{array}{c}\text { Adjusted R } \\
\text { Square }\end{array}$} & $\begin{array}{l}\text { Std. Error of the } \\
\text { Estimate }\end{array}$ & Durbin-Watson \\
\hline 1 & $.770^{\mathrm{a}}$ & .593 & .542 & .00519590 & 1.498 \\
\hline
\end{tabular}

Sumber: data diolah

Nilai dL yang didapat adalah 1.2428 nilai dU adalah 1.7835 nilai 4-dL adalah 2.7572 dan nilai 4-dU adalah 2.7835. Sedangkan nilai durbin Watson yang didapat adalah 1.498 yang artinya berada diantara nilai dL dan dU sehingga berada di daerah keragu-raguan.

\section{Uji F}

Tabel 6. Hasil Uji F

\begin{tabular}{|ll|r|r|r|r|r|}
\hline Model & Sum of Squares & $\mathrm{df}$ & Mean Square & $\mathrm{F}$ & Sig. \\
\hline 1 & Regression & .002 & 5 & .000 & 11.662 & $.000^{\mathrm{b}}$ \\
& .001 & 40 & .000 & & \\
Residual & .003 & 45 & & & \\
Total & & & & \\
\hline
\end{tabular}

Sumber: Data diolah 


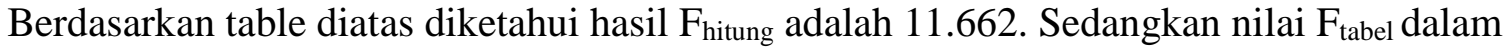
penelitian ini adalah 2,53. Karena $F_{\text {hitung }}>F_{\text {tabel }}$ sehingga hipotesis simultan dinyatakan diterima dengan tingkat signifikansi sebesar 0,000.

\section{Uji R Square}

\section{Tabel 7. Hasil Uji R Square}

\begin{tabular}{|l|r|r|r|r|}
\hline Model & $\mathrm{R}$ & R Square & Adjusted R Square & Std. Error of the Estimate \\
\hline 1 & $.770^{\mathrm{a}}$ & .593 & .542 & .00519590 \\
\hline
\end{tabular}

Sumber: Data diolah

Berdasarkan data datas dapat dilihat bahwa nilai Adjusted $R$ square adalah $54.2 \%$. Itu berarti sumbangsih variabel terikat (X) dalam penelitian ini terhada Y hanya 54.2\%. Sedangkan sisanya sebesar $45.8 \%$ bersumber dari penelitian lain.

\section{Regresi Linear Berganda}

Tabel 8. Hasil Uji Regresi Linear Berganda

\begin{tabular}{|c|c|c|c|c|c|c|c|}
\hline \multirow{2}{*}{\multicolumn{2}{|c|}{ Model }} & \multicolumn{2}{|c|}{ Unstandardized Coefficients } & \multirow{2}{*}{$\begin{array}{l}\text { Standardized } \\
\text { Coefficients } \\
\text { Beta }\end{array}$} & \multirow[b]{2}{*}{$\mathrm{t}$} & \multirow[b]{2}{*}{ Sig. } & \multirow{2}{*}{$\begin{array}{l}\text { Pada } \\
\text { bagian ini }\end{array}$} \\
\hline & & $\mathrm{B}$ & Std. Error & & & & \\
\hline \multirow[t]{6}{*}{1} & (Constant) & .027 & .006 & & 4.630 & .000 & menampil \\
\hline & IC & 8.019E-5 & .000 & .041 & .360 & .721 & kan garis \\
\hline & PSR & -.009 & .003 & -.391 & -3.521 & .001 & reareci \\
\hline & ZPR & -1.340 & .314 & -.520 & -4.261 & .000 & \\
\hline & EDR & .001 & .000 & .508 & 4.666 & .000 & \\
\hline & ISR & -.025 & .009 & -.287 & -2.678 & .011 & pengujia \\
\hline
\end{tabular}

nya. Persamaan garis regresi dapat diperoleh dari kolom standardized coefficients ( $\beta$ ). Jadi persamaan regresinya yaitu: $Y=\alpha+0.41 X_{1}-0.391 X_{2}-0,520 X_{3}+0.508 X_{4}-0.287 X_{5}$

\section{UJI HIPOTESIS}

\section{Pengaruh intellectual capital terhadap profitabilitas}

Berdasarkan data diatas nilai thitung $0,360<\mathrm{t}_{\text {tabel }} 2,021$ maka $\mathrm{H} 1$ ditolak. Tingkat signifikansi yang diperoleh adalah 0,721 > 0,05 yang dapat disimpulkan intellectual capital tidak berpengaruh terhadap profitabilitas. 


\section{Pengaruh profit sharing ratio terhadap profitabilitas}

Berdasarkan data diatas nilai t-hitung -3,521 > -2,021 maka H2 diterima. Tingkat signifikansi yang diperoleh adalah $0,001<0,05$ yang berarti proft sharing ratio berpengaruh positif terhadap profitabilitas.

\section{Pengaruh zakat performance ratio terhadap profitabilitas}

Berdasarkan hasil regresi linier berganda nilai t-hitung sebesar -4,261 > t-tabel -2,021 sehingga H3 diterima. Tingkat signifikansi yang diperoleh adalah $0,000<0,05$ maka dapat disimpulkan bahwa zakat performance ratio berpengaruh positif terhadap profitabilitas.

\section{Pengaruh equitable distribution ratio terhadap profitabilitas}

Berdasarkan hasil regresi linier berganda nilai t-hitung sebesar 4,666 > 2,021 sehingga H4 diterima. Tingkat signifikansi yang diperoleh sebesar 0,000 $<0,05$ maka dapat disimpulkan bahwa equitabel distribution ratio tidak berpengaruh terhadap profitabilitas.

\section{Pengaruh Islamic social reporting terhadap profitabilitas}

Berdasarkan hasil uji regresi linier berganda nilai t-hitung sebesar -2.687 > -2.021 sehingga H5 diterima. Tingkat signifikansi yang diperoleh adalah 0,011 $<0,05$ sehingga dapat disimpulkan bahwa Islamic social reporting berpengaruh positif terhadap profitabilitas.

\section{KESIMPULAN}

Berdasarkan hasil analisis data dan pembahasan terkait pengaruh intellectual capital, islamicity performance index dan corporate social responsibility terhadap profitabilitas bank umum syariah di Indonesia maka dapat di tarik kesimpulan sebagai berikut : (1) variabel intellectual capital tidak berpengaruh terhadap profitabilitas yang diukur menggunakan return on assets (ROA); (2) Profit sharing ratio berpengaruh positif terhadap profitabilitas yang diukur menggunakan return on assets (ROA); (3) Zakat performance ratio berpengaruh positif terhadap profitabilitas yang diukur menggunakan return on assets (ROA); (4) Equitable distribution ratio tidak berpengaruh terhadap profitabilitas yang diukur menggunakan return on assets (ROA); (5) Islamic social reporting mempunyai pengaruh positif terhadap profitabilitas yang diukur menggunakan return on assets (ROA). 


\section{SARAN}

Penelitian ini hanya dilakukan pada bank umum syariah yang ada di Indonesia tahun 2012-2018, sehingga disarankan kepada peneliti selanjutnya untuk mengembangkan populasi penelitian sehingga tidak hanya terhadap bank umum syariah saja. Adapun saran yang dapat diberikan peneliti untuk perusahaan adalah untuk bank umum syariah yang ada di Indonesia diharapkan agar mempertahankan kinerja laporan keuangan yang sudah cukup baik, sehingga dapat meningkatkan laba dan keuntungan perusahaan yang dapat meningkatkan minat para investor untuk berinvestasi pada perusahaan.

\section{DAFTAR PUSTAKA}

Bustamam, B., \& Aditia, D. (2016). Pengaruh Intellectual Capital, Biaya Intermediasi dan Islamicity Performance Index Terhadap Profitabilitas Syariah di Indonesia. Jurnal Dinamika Akuntansi Dan Bisnis, 3(1), 17-25. https://doi.org/10.24815/jdab.v3i1.4393

Chen, Y. C., Hung, M., \& Wang, Y. (2018). The effect of mandatory CSR disclosure on firm profitability and social externalities: Evidence from China. Journal of Accounting and Economics, 65(1), 169-190. https://doi.org/10.1016/j.jacceco.2017.11.009

Dewanata, P., Hamidah, H., \& Ahmad, G. N. (2016). the Effect of Intellectual Capital and Islamicity Performance Index To the Performance of Islamic Bank in Indonesia 2010-2014 Periods. JRMSI - Jurnal Riset Manajemen Sains Indonesia, 7(2), 259. https://doi.org/10.21009/jrmsi.007.2.04

Febriany, N. (2019). Pengaruh Intellectual Capital Terhadap Kinerja Keuangan Dan Pertumbuhan Perusahaan. Kompartemen: Jurnal Ilmiah Akuntansi, 17(1), 24-32. https://doi.org/10.17509/jrak.v3i2.6615

Harahap, N., Harmain, H., Siregar, S., \& Maharani, N. (2017). pengaruh islamic social reporting (ISR), umur perusahaan dan kepemilikan saham publik, terhadap profitabilitas (ROA) pada perusahaan yang terdaftar di jakarta islamic index (JII) tahun 2010-2014. KITABAH, 1(1), 70-91.

Herwanti, Titiek; Irwan, M. N. F. (2017). Disclosure Level's Effect of Islamic Social Reporting on Company's Profitability and Zakat. Management and Administrative Sciences Review, 6(2), 85-98.

Lisa, O. (2017). Analysis Macroeconomic On Islamicity Performance Index Through Fund Third Parties The Islamic Cooperation. International Journal of Social Science and Business, 1(1), 38. https://doi.org/10.23887/ijssb.v1i1.10161

Nasution, A. A., Lubis, A. F., \& Fachrudin, K. A. (2019). Sharia Compliance and Islamic Social Reporting on Financial Performance of the Indonesian Sharia Banks. 292(Agc), 640-644. https://doi.org/10.2991/agc-18.2019.96

Nurdin, S., \& Suyudi, M. (2019). Pengaruh Intellectual Capital Dan Islamicity Performance Index Terhadap Kinerja Keuangan Perbankan Syariah Di Indonesia. Jurnal Akuntansi 
Multidimensi, 2(2), 119-127

https://doi.org/10.21831/nominal.v5i1.11473

Prastuti, made cahyani, \& Budiasih, I. G. A. . (2019). Pengaruh Corporate Social Responsibility dan Intellectual Capital Pada Kinerja Keuangan Fakultas Ekonomi dan Bisnis Universitas Udayana (Unud), Bali, Indonesia

Pratiwi, A., Nurulrahmatia, N., \& Muniarty, P. (2020). Pengaruh Corporate Social Responsibility (CSR) Terhadap Profitabilitas Pada Perusahaan Perbankan Yang Terdaftar di BEI. Owner, 4(1), 95. https://doi.org/10.33395/owner.v4i1.201

Pudyastuti, L. W. (2018). Pengaruh Islamicity Performance Index dan Financing to Deposit Ratio (FDR) Terhadap Kinerja Keuangan Perbankan Syariah di Indonesia. Jurnal Manajemen $\begin{array}{lll}\text { Bisnis } & \text { Indonesia, } & \text { 170-181. }\end{array}$ http://journal.student.uny.ac.id/ojs/index.php/jmbi/article/view/12910

Puspitaningtyas, Z., Lestari, O. D., \& Prakoso, A. (2018). Penerapan Corporate Social Responsibility Terhadap Profitabilitas Perusahaan Barang Konsumsi yang Terdaftar di Bursa Efek Indonesia 2012-2016. Ekspektra: Jurnal Bisnis Dan Manajemen, 2(1), 89. https://doi.org/10.25139/ekt.v2i1.700

Putri, yiyi dian dwi, \& Gunawan, B. (2019). pengaruh intelectuall capital, efisiensi operasional, dan islamicity performance index terhadap profitabilitas bank syariah. Revieu Akuntansi Dan Bisnis Indonesia, 3(1), 38-49. https://doi.org/10.24815/jdab.v3i1.4393

Rahma, Y. (2018). The Effect Of Intellectual Capital And Islamic Performance Index On Financial Performance. Akuntabilitas, 11(1), 105-116. https://doi.org/10.15408/akt.v11i1.8804

Ridhawati, R. (2020). Pengukuran Kinerja Sosial Bank Umum Syariah (BUS) Berdasarkan Islamic Social Reporting Index (Indeks ISR) (Studi pada Bank Umum Syariah (BUS) yang terdaftar di Statistik Perbankan Syariah. 13(1), 17-31.

Sugiyono. 2016. METODE PENELITIAN kuantitaitif, kualitatif dan R\&D. Alfabeta : Bandung.

Wahyuni, S., \& Pujiharto, P. (2016). Profit efficiency of shariah banks in Indonesia and the determining factors: Using Stochastic Frontier Analysis Method. Journal of Economics, Business \& Accountancy Ventura, 19(2), 271. https://doi.org/10.14414/jebav.v19i2.711

Wahyuni, S., \& Pujiharto, P. (2018). Kinerja Keuangan Berbasis Shari'ate Value Added Approach: Komparasi Antara Bank Umum Sharia dan Unit Usaha Sharia di Indonesia. Kompartemen: Jurnal Ilmiah Akuntansi, 15(2), 111-127. https://doi.org/10.30595/kompartemen.v15i2.1972 